\title{
Impact of Fiscal Decentralisation on Economic Growth and Poverty Reduction in Aceh Province, Indonesia
}

\author{
Iqbal Firdaus ${ }^{1}$, Nunung Nuryartono ${ }^{2}$, Raul Barreto ${ }^{3}$ \\ ${ }^{*}$ BPS-Statistics of Lhokseumawe, Aceh Province, Indonesia \\ Corresponding author email: ibaldaus@gmail.com \& ibaldaus@bps.go.id ${ }^{1}$ \\ ${ }^{2}$ Department of Economics, IPB University, Bogor, West Java, Indonesia \\ ${ }^{3}$ School of Economics, The University of Adelaide, Adelaide, South Australia, Australia
}

\begin{abstract}
Article Info

Volume 8 Issue 1

Page Number: 176-185

Publication Issue :

January-February-2021

Article History

This study analyses the impact of fiscal decentralisation policy on economic development and poverty reduction. It focuses on the practice of intergovernmental fiscal transfer and on special autonomy policy in Aceh province, Indonesia, using data from 23 districts gathered from 2008 to 2018. Undertaking a panel data analysis, it will analyse the impact of intergovernmental fiscal transfer from central to local government on local government expenditure. The impact of local government expenditures and fiscal decentralisation practices on local gross domestic product (GDP) and poverty is also measured. The results show that several intergovernmental fiscal transfer policies in Aceh positively enhance the local expenditure. Further, the local government spending and fiscal decentralisation practices in Aceh improve the local GDP and reduce poverty levels in the region.
\end{abstract}

Accepted : 01 Feb 2021

Published : 08 Feb 2021
Keywords: Fiscal Decentralisation, Intergovernmental Fiscal Transfer, Special Autonomy, Government Expenditure

\section{INTRODUCTION}

To accelerate the achievement of national economic development goals, since 1999, the Indonesian Government has implemented a policy of fiscal decentralisation through the Indonesian Constitution No. 22 of 1999. By transferring part of its financial management authority to local governments, it aims to accelerate the progress of community welfare through improvement, services, empowerment and community participation, as well as by increasing regional competitiveness. The policy of fiscal decentralisation aims to improve regional financial performance through the decisions of regional expenditure and regional income.

Fiscal decentralisation in Aceh province, Indonesia is quite different from in most other provinces in Indonesia. Besides the general transfer of funds from the Indonesian Government, the province of Aceh also receives special, autonomous funds, unlike other provinces. Aceh has been labelled as a 'special' 
province which is mentioned in the Indonesian Constitution No. 18 of 2001 that Aceh was granted special autonomy (otonomi khusus). After a long rebellion era by the Free Aceh Movement (Gerakan Aceh Merdeka) and followed by military operation carried out by the Indonesian Government, a peace agreement was finally signed in August 2005. It is worth noting that the devastation caused by the 2004 Indian Ocean earthquake and tsunami in Aceh also helped to solidify this peace agreement. The authority of the special province of Aceh lies in the Constitution No. 11 of 2006, which specifically and broadly regulates the local governance of Aceh province and its regions, including in administrative, fiscal and policy decentralisation.

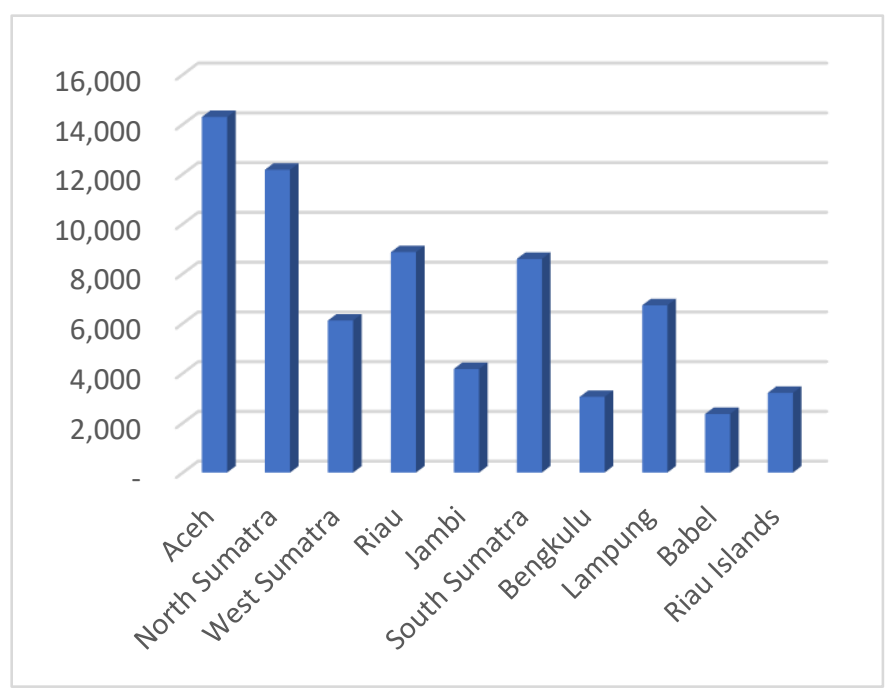

Source: Statistics Indonesia (BPS)

Figure 1 : Government Budgets for Sumatra Island, 2017 (Trillion Rupiah)

In 2017, Aceh had the highest local budget and was the largest fiscal transfer receiver in the Sumatra island. Aceh surpassed North Sumatra and Riau as the province with the most extensive budget. Figure 1 compares the local government budgets in the Sumatra region; it is evident that Aceh dominated the others with a budget of more than 14 trillion rupiah in 2017. Nationally, in the same year (2017), the total budget of Aceh province was in the fifth position. Figure 2 shows that Aceh was situated just below the large provinces of Jakarta, West Java, East Java and Central Java.

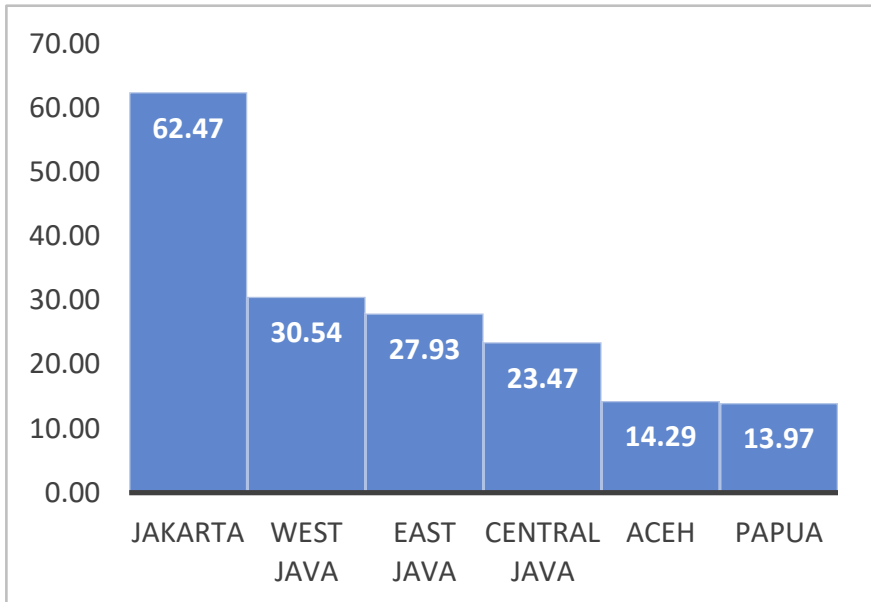

Source: Statistics Indonesia (BPS)

Figure 2 : Top Six Government Budgets in Indonesia, 2017 (Trillion Rupiah)

Ironically, with its huge budget for 2017, Aceh had the highest poverty level in the Sumatra region for that year, and the sixth highest in Indonesia. From 2012 to 2017 Aceh alternated with Bengkulu as the poorest province in the Sumatra region. Despite the initiation of special autonomy in 2008, the poverty rate in Aceh remains high. While there has been a slight decrease in poverty in Aceh, it has not been significant.

Figure 3 demonstrates that other provinces in the Sumatra region, such as Lampung and West Sumatra, have been better able to reduce poverty. Lampung decreased its poverty levels from $16.18 \%$ in 2012 to $13.69 \%$ in 2017, Riau Islands dropped its poverty percentages from $7.11 \%$ in 2012 to $6.06 \%$ in 2017 and West Sumatra reduced its percentage of people in poverty from $8.19 \%$ in 2012 to $6.87 \%$ in 2017 . Meanwhile, Aceh lowered its poverty rate from $19.46 \%$ in 2012 to only $16.89 \%$ with a much larger government budget. Arguably, the purpose of special autonomy is to build a better Aceh; however, this trend does not show noteworthy success, but only a slight improvement. 


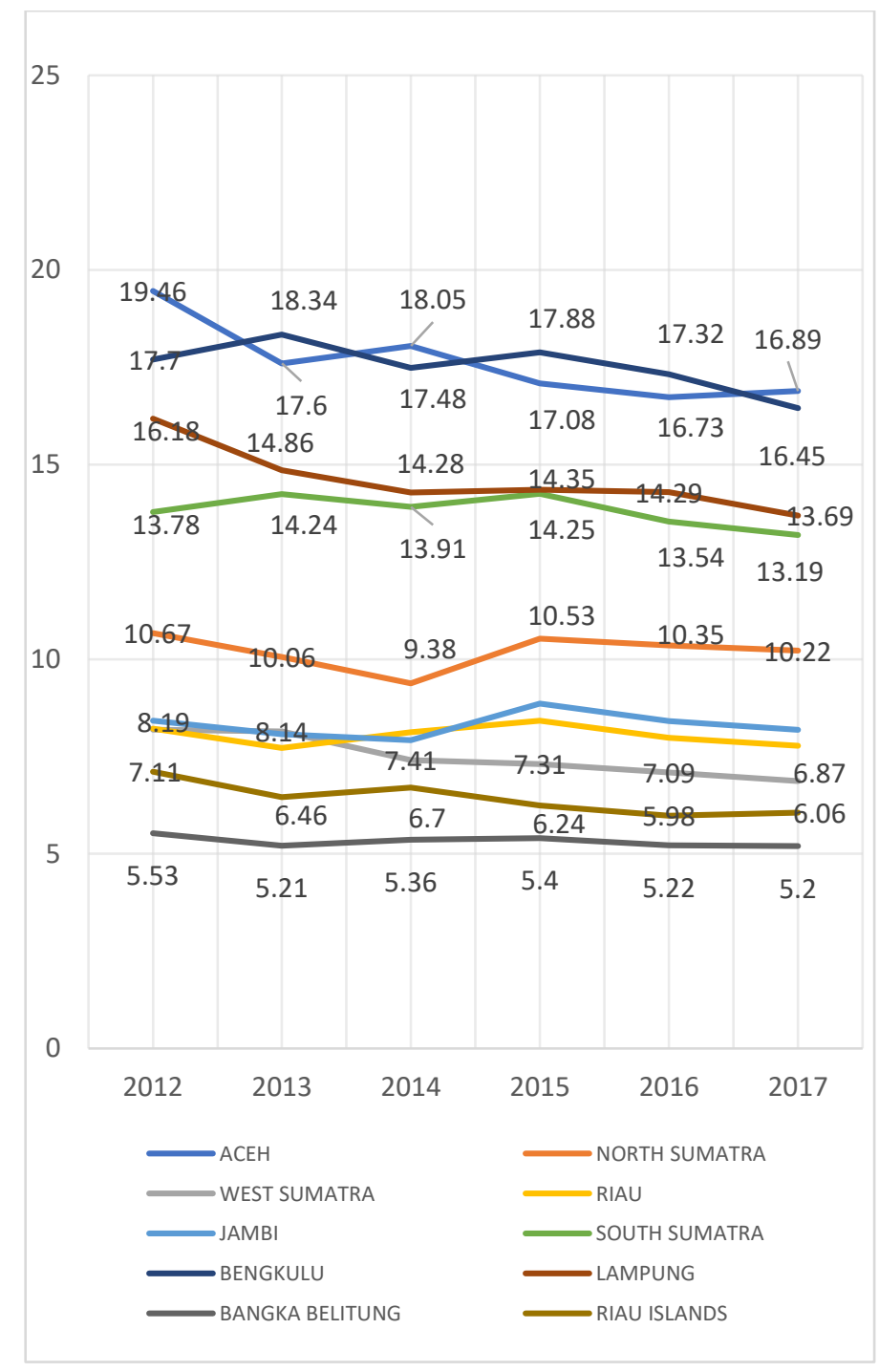

Source: Statistics Indonesia (BPS)

Figure 3 : Poverty Levels in Sumatra Island, 2012-2017 (Percentages)

This paper analyses the impact of fiscal decentralisation through government revenues and spending policy on local economic growth and poverty reduction. It will examine the influence of local government spending via fiscal transfer funds in general and special autonomy funds in particular to ascertain their effect on economic development and poverty reduction in Aceh, Indonesia, from 2008 to 2018.

The rest of the paper is arranged as follows. Section II discusses the data and methodology while section III presents the result and discussion of the study. In the next section, section IV provides conclusions and policy recommendations.

\section{DATA \& METHODOLOGY}

The secondary data used in this study were collected from various sources such as Bureau of Statistics (BPS), annual reports published by the Ministry of Finances and Aceh's provincial and local governments. This study utilises the data from 2008 to 2018, with 2008 marking the commencement of special autonomy in Aceh. Despite regulation by the Constitution in 2006, the fiscal transfer only began in 2008, the base year of this study. As data from 2019 are currently unavailable, 2018 marks the latest period considered in this study.

The operational definition of each variable used is as follows:

1. General allocation funds (DAU) originate from the national/state budget (APBN), which is allocated to regions with the aim of the equal distribution of inter-regional finances to facilitate expenditure needs in the context of implementing decentralisation.

2. The special allocation funds (DAK) are transferred from the central government to certain regions with the aim of funding special activities that are the affairs of the regional government but accord with national priorities.

3. Profit-sharing funds (DBH) are sourced from the APBN revenues and allocated to regions based on percentages of tax and natural resources to fund regional needs in the context of implementing decentralisation.

4. Locally generated revenues (PAD) are incomes obtained by the regions that are collected based on regional regulations in accordance with statutory rules in the context of implementing decentralisation.

5. The special autonomy funds (Otsus) are provided by the central government to regional 
governments with special autonomy rights to finance their regional development in the context of implementing decentralisation and special autonomy.

6. Regional expenditures are made within a certain fiscal year. Local government goods and services expenditures (BBJ) are for operational needs to carry out routine government activities, including personnel expenditures, goods expenditures and other expenses. Local government capital expenditures (BBM) generate added value to assets, both physical and non-physical, and are made within a certain period.

7. The GRDP is value the value of the goods and services produced by all economic activities in the regions and is measured based on a certain period from the base year so that the value truly reflects the amount of production free from price effects.

8. The poverty rate is the percentage of poor people in a ratio with the total population of an area. It accounts for those who experience an average per capita expenditure per month below the poverty line in relation to the total population.

9. Gross fixed capital formation (PMTB), is defined as the acquisition of produced assets, including purchases of second-hand assets and the production of such assets by producers for their own use, minus disposals.

This study uses panel data regression for its quantitative analysis. Several regression models are presented. However, in general, this tool is used to determine the impact of intergovernmental fiscal transfer policy on government expenditure in all Aceh regions. Later, the impact of this government expenditure on goods and services and on the capital for economic growth and poverty reduction is measured.

Four panel regression models are analysed in this study:
1. The first analyses the impact of fiscal decentralisation in the form of the intergovernmental fiscal transfer of DBH, DAU, DAK and the special autonomy funds (Otsus) on local public goods and services expenditure.

$\ln B B B_{i t}=\alpha_{i t}+\ln D B H_{i t}+\ln D A U_{i t}+\ln D A K_{i t}+\ln P A D_{i t}+\operatorname{lnOTSUS} S_{i t}+\varepsilon_{i t}$

2. The second analyses the impact of fiscal decentralisation in the form of the intergovernmental fiscal transfer of DBH, DAU, DAK and the special autonomy funds (Otsus) on local public capital expenditure.

$\ln B B M_{i t}=\alpha_{i t}+\ln D B H_{i t}+\ln D A U_{i t}+$

$\ln D A K_{i t}+\ln P A D_{i t}+\ln O T S U S_{i t}+\varepsilon_{i t}$

3. The third analyses the impact of local government spending (goods, services and capital), the fiscal decentralisation practice of locally generated revenue collection (PAD) and the special autonomy fund (Otsus) on regional GDP.

$\overline{\operatorname{lnGRDP}}{ }_{i t}=\alpha_{i t}+\ln B B J_{i t}+\ln B B M_{i t}+\ln P M T B_{i t}+\ln P A D_{i t}+\operatorname{lnOTSUS}_{i t}+\varepsilon_{i t}$

4. The fourth analyses the impact of local government spending (goods, services and capital), the fiscal decentralisation practice of locally generated revenue collection (PAD) and the special autonomy fund (Otsus) on poverty reduction.

$P_{P V R_{i t}}=\alpha_{i t}+\ln B B J_{i t}+\ln B M_{i t}+\ln G R D P_{i t}+\ln P A D_{i t}+\operatorname{lnOTSUS} i t+\varepsilon_{i t}$

\section{RESULTS AND DISCUSSION}

Overall, the share of special autonomy fund (Otsus) in total Aceh budget is very substantial. The special autonomy fund has become a main source of revenue for the Aceh expenditure budget. Table 1 displays that over the years, from 2014 to 2018, the contribution of Otsus fund in Aceh province on average is more than $60 \%$ every year. In districts level, the figures also show positive trends in general. This Otsus fund has exceeded other fiscal transfer from central government (DAU, DAK, DBH) and locally generated revenue $(\mathrm{PAD})$. 
Table 1 : Shares of PAD and Otsus on Total Government of Aceh Budget

\begin{tabular}{|l|l|l|l|l|l|}
\hline & 2014 & 2015 & 2016 & 2017 & 2018 \\
\hline $\begin{array}{l}\text { Otsus } \\
\text { Fund }\end{array}$ & $7,286,776$ & $8,080,416$ & $8,727,252$ & $8,206,138$ & $8,330,110$ \\
\hline PAD & $1,731,131$ & $1,972,049$ & $2,060,181$ & $2,276,306$ & $2,359,385$ \\
\hline $\begin{array}{l}\text { Total } \\
\text { Budget }\end{array}$ & $12,045,847$ & $12,135,635$ & $12,119,713$ & $13,832,849$ & $12,306,306$ \\
\hline $\begin{array}{l}\text { Otsus } \\
\text { Fund } \\
\text { Ratio }\end{array}$ & 60.49 & 66.58 & 72.01 & 59.32 & 67.69 \\
\hline $\begin{array}{l}\text { PAD } \\
\text { Ratio }\end{array}$ & 14.37 & 16.25 & 17.00 & 16.46 & 19.17 \\
\hline
\end{tabular}

Source : Ministry of Finance and Aceh Local Government

However, there is two contrasting argument regarding the dominance of this Otsus. On the one hand, this is a good thing, because it shows that the central government is very concerned with the ongoing development of Aceh province. It also demonstrates that the central government follow an important point of the peace agreement of $\mathrm{MoU}$ Helsinki which is to build a better Aceh through national funds. On the other hand, this huge share of budget might also create dependency of Aceh government on Otsus fund, which is not good. As previously mentioned, this Otsus fund will only last for 20 years since the implementation of this policy, which is in 2008. Therefore, when Otsus fund is ending, this dependency might interfere with the ongoing development of Aceh in the future.

Hence, in terms of the fiscal decentralisation policy, the capability of local regions to collect locally generated revenue is worth reviewing. In general, the figures for own-source revenue collection (PAD) in all districts are increasing. The data indicates positive trends of local government revenue accumulation in Aceh province. The share of locally generated revenue (PAD) itself from Table 1 shows an increasing trend. Generally, the share of PAD to the total budget is approximately $15 \%$ every year on average. For that reason, it can be said that, slowly all the districts in Aceh starting to improve their responsibility and authority to manage their regional financial resources to develop their regions. This PAD will be essential in the future for the Aceh government when Otsus fund will not be provided anymore by the central government.

Panel regression analysis will be explained into four models. The first model examines the impact of fiscal decentralisation on local government expenditure, particularly on goods and services. Fiscal decentralisation in entails intergovernmental transfers, such as DBH, DAU, DAK and also Otsus funds. Meanwhile, local regions have the capacity to collect their own revenue, which is another form of fiscal decentralisation measured by PAD.

The first model can be written as follows:

$\operatorname{lnBB}]_{i t}=7.503-0.219 \operatorname{lnDBH}_{\text {it }}+0.072 \operatorname{lnDAU} U_{\text {it }}+0.138 \operatorname{lnDAK}_{\text {it }}+0.392 \operatorname{lnPAD}_{\text {it }}$ $-0.014 \ln 0$ tsus it $+\varepsilon_{\text {it }}$

The first model from the table shows that several elements of fiscal decentralisation policy significantly affect government expenditure in goods and services. The variables $\mathrm{DBH}$, is significant at $\overline{\alpha=5 \%}$, DAK at 


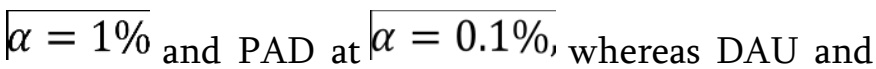
Otsus are not. Two fiscal decentralisation components, DAK and PAD, can be seen to positively increase local goods and services expenditure. The impact of $\mathrm{PAD}$ is greater than that of $\mathrm{DAK}$, at $0.392 \%$ and $0.138 \%$, respectively. Meanwhile, one significant other, DBH, negatively affects local government good and services expenditure, at $0.219 \%$.

The second model analyses the impact of fiscal decentralisation on local government capital expenditures. All the independent variables are similar to those in the previous model, representing fiscal decentralisation practices.

The second model can be written as follows:

$\operatorname{lnBBM} M_{\text {it }}=7.436+0.206 \operatorname{lnDBH}_{\text {it }}-0.555 \operatorname{lnDAU} U_{\text {it }}+0.329 \operatorname{lnDAK}$ it $+0.4891 \operatorname{lnPAD}_{\text {it }}$ $+0.059 \ln 0$ tsus $_{\mathrm{it}}+\varepsilon_{\mathrm{it}}$

The result shows that all variables are significant at $\alpha=5 \%$. This means that all components of the fiscal decentralisation policy significantly affect local government capital expenditure. Four out of five intergovernmental fiscal transfer components positively affect local capital expenditure. The one with the greatest influence was the PAD variable at $0.489 \%$, then DAK at $0.329 \%, \mathrm{DBH}$ at $0.206 \%$ and, last, Otsus at $0.059 \%$. However, the impact of the DAU variable on local government capital expenditure is negative. The increase in the DAU fiscal transfer reduces the local government capital expenditure by around $0.55 \%$.

The third model investigates the impact of government expenditure and the special autonomy fund on economic development. The PMTB variable is used as control variable. Economic development is measured using GRDP. This model also examines the impact of special autonomy funds on economic development in terms of GDP improvement.

The third model can be written as follows: $\left.\operatorname{lnGRDP} P_{i t}=9.401+0.109 \operatorname{lnBB}\right]_{i t}-0.016 \operatorname{lnBBM}_{\text {it }}+0.314 \operatorname{lnPMTB} \mathrm{it}_{\mathrm{it}}+0.012 \ln 0$ tsus $\mathrm{sit}_{\mathrm{it}}+\varepsilon_{\mathrm{it}}$
The result shows that three out of four variables are significant at $\alpha=5 \%$ and have positive impacts on the economy. PMTB, as a control variable, has the largest positive impact on the economy at $0.314 \%$. Local government expenditure on goods and services has a positive effect on GRDP development, but local spending via capital expenditure has no significant influence on GRDP improvement in this model. The special autonomy fund (Otsus) positively affects the escalation of local economy, albeit only to a small extent at $0.012 \%$.

The fourth model studies the impact of government expenditure and the implementation of fiscal decentralisation on poverty reduction. The impact of local government expenditure is classified into goods and services expenditure and capital expenditure. Fiscal decentralisation was partially analysed in this model using the capabilities of local regions to collect their own revenue (PAD) when using special autonomy funds (Otsus).

The fourth model can be written as follows:

PovRate $\left._{i t}=95.92-0.013 \ln B B\right]_{i t}+1.357 \ln B B M_{i t}-4.621 \ln$ RDDP $_{i t}-1.739 \ln \operatorname{PAD}_{\text {it }}$ $-0.491 \ln 0 t s u s_{\text {it }}+\varepsilon_{\text {it }}$

The result indicates that local spending on goods and services does not significantly affect poverty alleviation. However, local capital expenditure worsens the poverty rate, as its impact is positive at $1.357 \%$. The negative impact of capital expenditure on poverty rate could happen if there is a large number of corruptions in local regions. The other three variables, GRDP, PAD and Otsus, each play significant roles in reducing the poverty rate. Local GDP has the most significant impact on lowering the figure of local poverty rate, followed by PAD. However, the impact of Otsus is only minor at $0.5 \%$.

\section{CONCLUSION \& RECOMMENDATIONS}

Aceh is a special province with a special autonomy status. The decentralisation affecting Aceh is slightly 
different than in other regions. In the past, provinces such as Aceh and Papua have sought to separate themselves from the Republic of Indonesia in response to central government policies. However, as an alternative, the central government granted special autonomy to the Aceh and Papua provinces. From 2008 until today, Aceh, as a special autonomy province, has received a special autonomy budget from the central government.

Until this year, the proportion of this Otsus fund has been essential for the Aceh province. The Aceh province's increasing budget on a national level over the past year results from the significant amount of special autonomy funds comprising the local Aceh budget (APBD) and transferred from the central government. The purpose of the special autonomy fund is to encourage regions with special autonomy status to increase their economic development. However, the local government should slowly introduce and improve its capacity to collect locally generated revenue $(\mathrm{PAD})$ as an alternative to fiscal transfers from the central government.

Despite the high level of poverty in the Aceh province, the percentage of poor citizens is decreasing. In general, the figures across all regions are experiencing a drop in their poverty levels. This is also true for local GDPs, as all districts are generally increasing their GDP levels. However, the changes vary among districts and may need to be analysed separately at a district level.

The results from the data panel analysis show the positive impact of the fiscal decentralisation policy on government expenditure levels. Several elements of intergovernmental fiscal transfers, such as DBH and DAK, significantly affect local goods and services expenditure. In addition, PAD, as the capacity of local regions to collect their own revenue, is affecting local goods and services expenditure. Meanwhile, all variables significantly influence the local government capital expenditure. Only one variable, DBH, negatively affects the local capital expenditure while the rest of variables (DAU, DAK, PAD, Otsus) have positive impacts on local capital spending.
This study also finds an impact of fiscal decentralisation on economic development and poverty. The analysis shows a positive influence of fiscal decentralisation on economic development. The panel regression result indicates that local government spending in goods and services improves the local GDP. Two other variables, PMTB and the Otsus fund, also positively affect local GDP. In terms of the impact on poverty, the analysis shows that the Otsus fund reduces the poverty rate, but only to a small extent. Further, the improvement of local GDP (GRDP) and local government capabilities in terms of collecting own revenue (PAD) proven as a good instrument of lessen the poverty figures.

The special autonomy fund (Otsus) proven to be a good enough policy of fiscal decentralization in Aceh province. Overall, from panel data regression analysis, the Otsus fund positively enhance local government expenditure, escalate local GDP and more importantly reduce the poverty level. Nonetheless, the impact of this Otsus fund is not that big. For that reason, in the remaining years of special autonomy funds, the supervision of the use of the special autonomy funds need to be improved, either from central government or Aceh province in hoping that the impact of Otsus fund could become greater. This is important because the amount of Otsus fund received by Aceh over the year is massive. In addition, further analysis in all districts need to be investigate separately to get better insights and details of fiscal decentralisation impact in smaller regional levels.

\section{REFERENCES}

[1]. Abrar, M, Juanda, B, Firdaus, M \& Hakim, DB 2018, 'The Effect of Special Autonomy Funds on Economic Growth and Income Inequality in Aceh Province', Journal of Applied Economic Sciences, vol. 13, no. 7.

[2]. Akhsyim, A, Dwi, W \& Jaka, S 2017, 'Policies to Eliminate Poverty Rate in Indonesia', International journal of economics and financial issues, vol. 7, no. 1, pp. 435-441. 
[3]. Ali Khan, S 2013, 'Decentralization and Poverty Reduction: A Theoretical Framework for Exploring the Linkages', International review of public administration, vol. 18, no. 2, pp. 145172.

[4]. Bachtiar, R 2018, 'Critically Examining the Arrangements of Fiscal Decentralization in Indonesia', Jurnal Transformative, vol. 4, no. 2, pp. 79-92.

[5]. Besley, T \& Coate, S 2003, 'Centralized versus decentralized provision of local public goods: a political economy approach', Journal of Public Economics, vol. 87, no. 12, pp. 2611-2637.

[6]. Brodjonegoro, B 2004, 'Three years of fiscal decentralization in Indonesia: Its impact on regional economic development and fiscal sustainability', in International Symposium on Fiscal Decentralization in Asia Revisited, Hitotsubashi University, Tokyo.

[7]. Buser, W 2011, 'The impact of fiscal decentralization on economics performance in high-income OECD nations: an institutional approach', Public choice, vol. 149, no. 1-2, pp. 31-48.

[8]. de Janvry, A \& Sadoulet, E 2010, 'Agricultural growth and poverty reduction: Additional evidence', The World Bank Research Observer, vol. 25, no. 1, pp. 1-20.

[9]. Debrah, E 2014, 'The Politics of Decentralization in Ghana's Fourth Republic', African studies review, vol. 57, no. 1, pp. 49-69.

[10]. Decentralization and Governance in Indonesia 2016, Development and Governance, 2, 1st ed. 2016. edn, eds RL Holzhacker, R Wittek \& J Woltjer, Springer International Publishing, Cham.

[11]. Dufhues, T, Theesfeld, I \& Buchenrieder, G 2015, 'The Political Economy of Decentralization in Thailand: How Past and Present Decentralization Affects Rural Actors' Participation', European journal of development research, vol. 27, no. 5, pp. 793810.
[12]. Edmund, JM \& Francis, EH 2016, 'Varieties of Disappointment: Why Has Decentralization Not Delivered on Its Promises in Southeast Asia?', Journal of Southeast Asian Economies, vol. 33, no. 2, pp. 125-138.

[13]. Fiscal Decentralization and Development: Experiences of Three Developing Countries in Southeast Asia 2012, ed. H Uchimura, Palgrave Macmillan.

[14]. Fiscal federalism 2014: making decentralisation work 2013, OECD Publishing, Paris.

[15]. Gonschorek, GJ \& Schulze, GG 2018, 'Continuity or Change? Indonesia's Intergovernmental Fiscal Transfer System under Jokowi', Journal of Southeast Asian Economies, vol. 35, no. 2, pp. 143-164.

[16]. Hartati, ES 2012, 'Dampak Komposisi Belanja Pemerintah Terhadap Pertumbuhan Ekonomi, kesempatan Kerja dan Tingkat Kemiskinan', Faculty of Economy and Management, IPB University, Bogor, Indonesia.

[17]. Hasugian, AM 2006, 'Dampak Desentralisasi Fiskal terhadap Kinerja Keuangan Daerah dan Kemiskinan di Kabupaten dan Kota Provinsi Jawa Barat', Faculty of Economy and Management, IPB University, Bogor, Indonesia.

[18]. Hammond, GW \& Tosun, MS 2011, 'The Impact of Local Decentralization on Economic Growth: Evidence from U.S. Counties', Journal of regional science, vol. 51, no. 1, pp. 47-64.

[19]. Indah, SP 2011, 'Analisis Dampak Desentralisasi Fiskal dan Pengaruhnya Terhadap PDRB, Tenaga Kerja, dan Kemiskinan di Provinsi Jawa Barat', Faculty of Economy and Management, IPB University, Bogor, Indonesia.

[20]. Intergovernmental fiscal transfers principles and practices 2006, Public sector governance and accountability series, eds RW Boadway \& A Shah, World Bank, Washington, DC.

[21]. Kai, O, Yuhki, T \& Krislert, S 2016, 'Indonesia's Decentralization Experiment: Motivations, Successes, and Unintended Consequences', 
Journal of Southeast Asian Economies, vol. 33, no. 2, pp. 139-156.

[22]. Kaludjerovic, J, Mirković, M \& Jocović, M 2017, 'The Impact of Fiscal Decentralisation on Local Economic Development in Montenegro', Lex localis-journal of local self-government, vol. 15, no. 3, pp. 685-703.

[23]. Lai, Y \& Cheng, T 2011, 'Intergovernmental Allocation of Public Resources, Fiscal Decentralization and Economic Growth', International Journal of Information Engineering and Electronic Business, vol. 3, no. 3, pp. 8-15.

[24]. Lewis, B 2013, 'Local government capital spending in Indonesia: Impact of intergovernmental fiscal transfers', Public Budgeting \& Finance, vol. 33, no. 1, pp. 76-94.

[25]. Maličká, L, Šulíková, V \& Šoltés, M 2017, 'Relationship between Fiscal Decentralization and Economic Growth in European Union Countries and Slovakia', Ekonomický časopis, vol. 65, no. 9, pp. 856-875.

[26]. Mankiw, NG 2010, Macroeconomics, 7th ed. edn, Worth Publishers, New York, NY.

[27]. Muda, I \& Ridha, H 2018, 'Effect of Revenue and General Allocation Fund of Capital Expenditures in the Economic Growth as Moderator Variable. Case of Indonesia', Academic journal of economic studies, vol. 4, no. 1, pp. 29-39.

[28]. Mudayen, YMV \& Maridjo, H 2018, 'The Impacts of Fiscal Decentralization, Institutional Transformation, and Regional Revenue on Income Disparities between Provinces in Indonesia', Journal of Economics, Business \& Accountancy Ventura (Online), vol. 20, no. 3, pp. 247-259.

[29]. Pepinsky, T \& Wihardja, M 2011, 'Decentralization and Economic Performance in Indonesia', Journal of East Asian Studies, vol. 11, no. 3, pp. 337-371,515-516.

[30]. Rodriguez-Pose, A \& Ezcurra, R 2010, 'Is fiscal decentralization harmful for economic growth?
Evidence from the OECD countries', Journal of economic geography, vol. 11 , no. 4, pp. 619643.

[31]. Sartiyah, s, Sri, H, Syaukat, Y \& Oktaviani, R 2017, 'The Effect of Government Spending on Education to Human Capital in Aceh Province', Journal of economic development, environment and people, vol. 6, no. 4, pp. 18-28.

[32]. Schneider, A 2003, 'Decentralization: Conceptualization and measurement', Studies in comparative international development, vol. 38, no. 3, pp. 32-56.

[33]. Sepulveda, CF \& Martinez-Vazquez, J 2011, 'The Consequences of Fiscal Decentralization on Poverty and Income Equality', Environment and planning. C, Government \& policy, vol. 29, no. 2, pp. 321-343.

[34]. Shahid, M \& Kalim, R 2020, 'Decentralized Tax Revenue, Institutional Complementarity and Economic Growth: A Time Series Analysis of Pakistan', International journal of economics and financial issues, vol. 10, no. 4, pp. 25-33.

[35]. Stiglitz, J. E. (2000). Economics of the public sector. New York, W.W. Norton.

[36]. Sudhipongpracha, T \& Wongpredee, A 2017, 'Fiscal Decentralization in Comparative Perspective: Analysis of the Intergovernmental Grant Systems in Indonesia and Thailand', Journal of Comparative Policy Analysis: Research and Practice, vol. 19, no. 3, pp. 245261.

[37]. Syaifudin, N, Sutrisno, A \& Setiawan, AD 2015, 'The impact of fiscal transfer on energy efficiency in Indonesia', Energy Procedia, vol. 65, pp. 239-247.

[38]. The Government of Indonesia. Constitution No. 22 of 1999, No. 25 of 1999, No. 18 of 2001, No. 33 of 2004, No. 11 of 2006 and No. 23 of 2014. Republic of Indonesia State Gazette No. 3839, 3848, 4134, 4438, 4633, 5587, State Secretariat. Jakarta

[39]. Vu Thanh Tu, A 2016, 'Vietnam: Decentralization Amidst Fragmentation', 
Journal of Southeast Asian Economies, vol. 33, no. 2, pp. 188-208.

[40]. World Bank 2013, Fiscal Decentralization, viewed $\quad 10 \quad$ February 2020, $<$ http://www1.worldbank.org/publicsector/dece ntralization/fiscal.htm>.

[41]. Zhang, $\mathrm{T}$ \& Zou, H-f 1998, 'Fiscal decentralization, public spending, and economic growth in China', Journal of Public Economics, vol. 67, no. 2, pp. 221-240

\section{Cite this article as :}

Iqbal Firdaus, Nunung Nuryartono, Raul Barreto, "Impact of Fiscal Decentralisation on Economic Growth and Poverty Reduction in Aceh Province, Indonesia", International Journal of Scientific Research in Science, Engineering and Technology (IJSRSET), Online ISSN : 2394-4099, Print ISSN : 2395-1990, Volume 8 Issue 1, pp. 176-185, JanuaryFebruary 2021. Available at doi : httpss://doi.org/10.32628/IJSRSET218130

Journal URL : https://ijsrset.com/IJSRSET218130 